\title{
PERSPECTIVE
}

\section{'No, really, how do they work?'}

\author{
David D. Moore \\ Department of Molecular and Cellular Biology, Baylor College of Medicine, Houston, Texas 77030, USA
}

"How do the antidiabetic thiazolidinediones work?" If your 3-yr-old asked this question it would be easy to answer: "They function as agonists to activate PPAR $\gamma$. " Inquisitive minds being what they are, this answer would suffice only for a moment and a more incisive query would soon follow: "But how does PPAR $\gamma$ activation affect diabetes?" You could keep the cycle going for another round by responding: "When it is activated, $\operatorname{PPAR} \gamma$ turns on the expression of appropriate target genes that function to increase insulin sensitivity." And you might manage to delay the inevitable by handing her a printout of PPAR $\gamma$ targets identified by gene arrays. But 3 -yr-olds are not easily sidetracked by such obvious ploys and you would soon face the inevitable "No, really, how do they work?"

In this issue, Lazar and colleagues (Guan et al. 2005) add an intriguing new answer that moves beyond some stereotypic assumptions about PPAR $\gamma$ and nuclear receptors. But appreciating it requires some examination of these assumptions.

Pioglitazone (Actos) and rosiglitazone (Avandia) are related thiazolidinedione (TZD) compounds that are widely prescribed insulin sensitizers, with yearly sales of each exceeding a billion dollars. Although they are indeed quite specific PPAR $\gamma$ agonists, they were not initially discovered by modern high-throughput screening approaches, as one might assume, but in decidedly lowthroughput animal-based screens for effects on insulin resistance (Fujita et al. 1983). Their identification as $\operatorname{PPAR} \gamma$ activators was based on the guesses of several groups (Forman et al. 1995; Lehmann et al. 1995) who managed to link a side effect of these compounds, their ability to promote adipogenesis, with the then recently identified role of PPAR $\gamma$ in that process.

In addition to their obvious therapeutic benefits, the TZDs have provided a remarkable pharmacologic tool to explore the pathology of type II diabetes, certainly one of the most important medical problems facing western populations today. This has sparked intense interest in the function of the PPARs, with $>3000$ papers in this area since 1990. Particularly considering the massive amount of new information on the mechanisms of transcriptional activation by nuclear hormone receptor agonists, one might also assume that the molecular basis for the

E-MAIL moore@bcm.tmc.edu; FAX (713) 798-3017.

Article and publication are at http://www.genesdev.org/cgi/doi/10.1101/ gad.1294105. antidiabetic effects of TZDs, particularly the identity and the functions of the therapeutically relevant target genes induced by PPAR $\gamma$, would be well known. But that is only partly right.

The main problem is that PPAR $\gamma$ acts in adipose tissue, while insulin acts primarily in other tissues, notably skeletal muscle and liver. A number of solutions have been proposed, and many have good experimental support. While it is not possible to adequately address this issue here (for reviews, see Picard and Auwerx 2002; Rangwala and Lazar 2004), PPAR $\gamma$ activation in adipocytes is thought to improve metabolic parameters at the whole-body level, for example by increasing fat deposition and decreasing serum levels of free fatty acids, which inhibit insulin signaling. Importantly, PPAR $\gamma$ activation in adipocytes also modulates production of an emerging and in some cases still controversial series of adipocytokines, increasing expression of factors thought to promote insulin action, such as adiponectin, and decreasing expression of inhibitory signals, such as TNF $\alpha$ and resistin.

So how do TZDs really work? At one level, the continuing studies on the functions of both induced and repressed PPAR $\gamma$ target genes in fat and other tissues will provide a basic framework for understanding their effects. At a different level, the question is how TZDs actually alter expression of the functionally relevant targets, and this is where the studies from the Lazar lab raise and answer some unexpected questions.

The specific question they addressed was relatively simple: Why are some PPAR $\gamma$ target genes induced as its levels increase during adipogenesis, while others are expressed at low levels in adipocytes and dramatically upregulated by TZDs? In their studies, the first group was exemplified by the classic target aP2, and glycerol kinase (GyK) represented the second. In adipocytes, PPAR $\gamma$ binds to its response element in the aP2 promoter and recruits a variety of coactivators, resulting in histone modification and eventually RNA polymerase binding and transcription. Neither PPAR $\gamma$ binding nor coactivator recruitment is affected by TZD treatment. To characterize the GyK response, Guan et al. (2005) first identified a conventional DR-1 PPAR/RXR-binding site upstream of its basal promoter and ruled out one obvious answer to their question by showing that this element is bound by PPAR $\gamma$ in the absence of TZD treatment. As expected, all of the coactivator recruitment and histone modifications observed for $\mathrm{aP} 2$ are also seen with the 


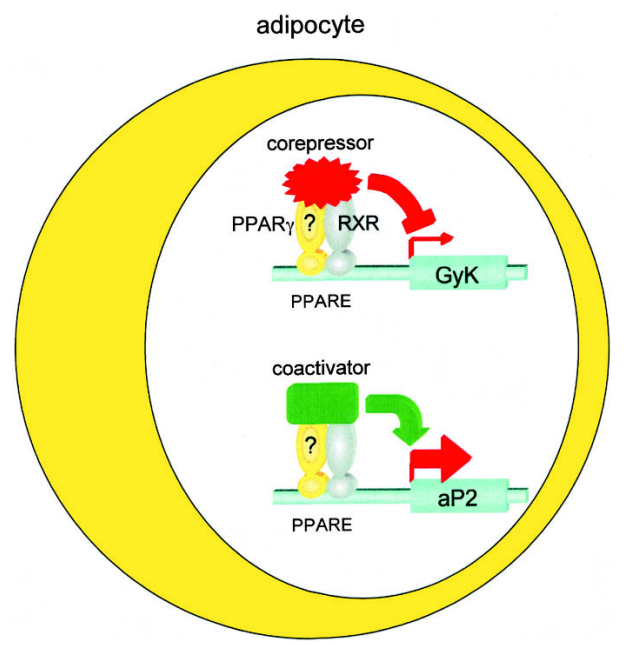

Figure 1. One receptor-one cell-different outputs. PPAR $\gamma$ is bound by an as yet unknown ligand (?) in adipocytes. This results in coactivator recruitment and transcriptional activation of some genes like aP2. Recruitment of corepressors by the same receptor inhibits expression of genes like glycerol kinase (GyK).

GyK element in TZD-treated cells where the gene is active, but they are absent in the untreated cells. Guan et al. (2005) solve the mystery of why the PPAR $y$ bound to the GyK element does not activate transcription in these untreated cells with the quite unexpected demonstration that it recruits the corepressors SMRT and NCoR and the histone deacetylase HDAC3 to GyK (Fig. 1). Several approaches confirm that $\mathrm{GyK}$ expression is negatively regulated by these factors in the untreated adipocytes, and show that they are displaced by TZD treatment.

In another surprise, overexpression of the coactivator PGC- $1 \alpha$ also results in decreased corepressor binding to GyK and increased basal expression, but in agreement with previous studies, does not affect aP2 expression. TZD treatment induces PGC- $1 \alpha$ expression in adipocytes. Thus, TZDs presumably regulate GyK expression directly by displacing corepressors from and recruiting other coactivators to PPAR $\gamma$, and indirectly by increasing PGC- $1 \alpha$ levels.

As always, answering one question raises others. In particular, how can the same receptor in the same cells bring corepressors to one gene and coactivators to another? Obviously there must be something different about the genes, and it could be either the sequence of the PPAR $\gamma$ response elements themselves or the activity of other nearby proteins. The former appears to be ruled out by the fact that replacement of the GyK-binding site with the aP2 site did not alter the TZD responsiveness of the promoter. Thus, the unfortunately murky concept of "promoter context" is presumably the answer.

What does this tell us about how TZDs work? At the most basic level, we now know that they can directly regulate gene expression not only by promoting coactivator binding, but also by dismissing corepressors. As pointed out by Guan et al. (2005), this suggests that se- lective PPAR $\gamma$ ligands that block corepressor binding but do not recruit coactivators might increase expression of genes leading to insulin sensitivity while avoiding undesirable side effects such as adipogenesis.

Over the last several years the potential effects of partial agonists and antagonists have gotten increased attention, and it is well known that individual nuclear receptor ligands can both induce and repress target gene expression. The current results take these concepts one step further by suggesting that distinct activation ligands for a single receptor may have opposite effects on expression of a single target gene in a single cell. For GyK, TZDs and the intriguing but elusive endogenous PPAR $\gamma$ ligand in adipocytes (Tzameli et al. 2004) provide one example. Based on differential repressive effects of LXR $\alpha$ in macrophages and intestine (Wagner et al. 2003), endogenous and synthetic LXR ligands may also have similar disparate effects. Perhaps this is a trick that Mother Nature knows well.

\section{References}

Forman, B.M., Tontonoz, P., Chen, J., Brun, R.P., Spiegelman, B.M., and Evans, R.M. 1995. 15-Deoxy- $\delta$ 12, 14-prostaglandin 22 is a ligand for the adipocyte determination factor PPAR $\gamma$. Cell 83: 803-812.

Fujita, T., Sugiyama, Y., Taketomi, S., Sohda, T., Kawamatsu, Y., Iwatsuka, H., and Suzuoki, Z. 1983. Reduction of insulin resistance in obese and/or diabetic animals by 5-[4-(1-methylcyclohexylmethoxy/benzyl]-thiazolidine-2,4-dione (ADD3878 , U-63,287, ciglitazone), a new antidiabetic agent. Diabetes 32: 804-810.

Guan, H.-P., Ishizuka, T., Chui, P.C., Lehrke, M., and Lazar, M.A. 2005. Corepressors selectively control the transcriptional activity of PPAR $\gamma$ in adipocytes. Genes \& Dev. (this issue).

Lehmann, J.M., Moore, L.B., Smith-Oliver, T.A., Wilkison, W.O., Willson, T.M., and Kliewer, S.A. 1995. An antidiabetic thiazolidinedione is a high affinity ligand for peroxisome proliferator-activated receptor $\gamma$ (PPAR $\gamma)$. J. Biol. Chem. 270: 12953-12956.

Picard, F. and Auwerx, J. 2002. PPAR( $\gamma)$ and glucose homeostasis. Annu. Rev. Nutr. 22: 167-197.

Rangwala, S.M. and Lazar, M.A. 2004. Peroxisome proliferatoractivated receptor $\gamma$ in diabetes and metabolism. Trends Pharmacol. Sci. 25: 331-336.

Tzameli, I., Fang, H., Ollero, M., Shi, H., Hamm, J.K., Kievit, P., Hollenberg, A.N., and Flier, J.S. 2004. Regulated production of a peroxisome proliferator-activated receptor- $\gamma$ ligand during an early phase of adipocyte differentiation in 3T3-L1 adipocytes. J. Biol. Chem. 279: 36093-36102.

Wagner, B.L., Valledor, A.F., Shao, G., Daige, C.L., Bischoff, E.D., Petrowski, M., Jepsen, K., Baek, S.H., Heyman, R.A., Rosenfeld, M.G., et al. 2003. Promoter-specific roles for liver X receptor/corepressor complexes in the regulation of ABCA1 and SREBP1 gene expression. Mol. Cell Biol. 23: 5780-5789. 


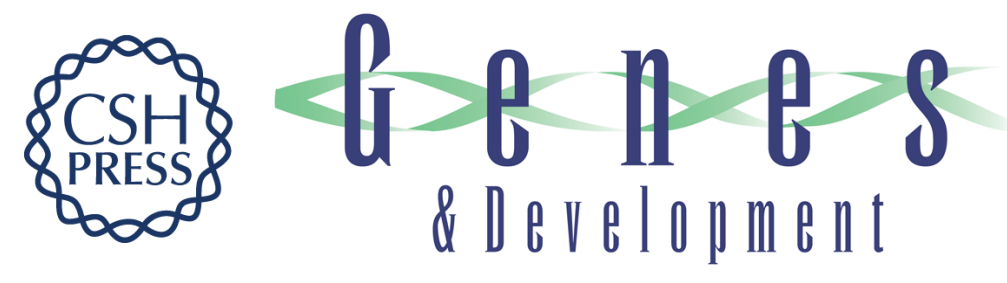

\section{'No, really, how do they work?'}

David D. Moore

Genes Dev. 2005, 19:

Access the most recent version at doi:10.1101/gad.1294105

References This article cites 7 articles, 4 of which can be accessed free at: http://genesdev.cshlp.org/content/19/4/413.full.html\#ref-list-1

License

Email Alerting Receive free email alerts when new articles cite this article - sign up in the box at the top Service right corner of the article or click here.

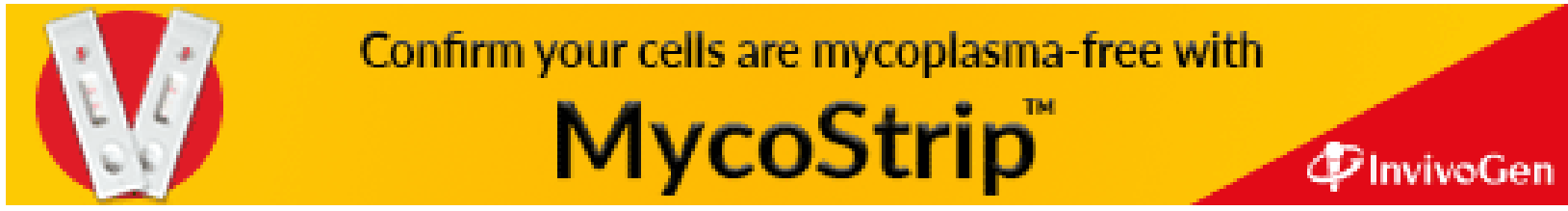

